\title{
Britský konzervatismus \\ na začátku devatenáctého století
}

\section{British Conservatism in the Early 19th Century}

\author{
Alan Sked / a.sked@lse.ac.uk \\ London School of Economics and Political Science, London, UK
}

\begin{abstract}
This study examines the issue of British conservatism in the early 19th century. The author first evaluates the role of the founding figure of British conservatism Edmund Burke, his thinking and influence on the tradition of Conservative political thought and in realpolitik in Britain from the end of the 18th century and in the first half of the following century. This topic is set within the context of British foreign and domestic policy.

\section{Keywords}

conservatism, British conservative politics, revolutionary France, Edmund Burke, radicalism, British foreign policy
\end{abstract}


V tomto článku budu pracovat s definicí konzervatismu, jak ji navrhl německý historik Hans-Gerd Schumann, který konzervatismus pokládal za „vědomé politické jednání, k němuž přistupují sociálně privilegované třídy, vrstvy či skupiny, aby zabezpečily instituce, v nichž je zakotveno jejich sociální postavení, proti snahám změnit normy převažující v politické sféře... ${ }^{11} \mathrm{~V}$ tomto rámci je užitečná typologie Klause Epsteina rozlišující tř̌i typy konzervativců - totiž konzervativce status quo, reformní konzervativce a reakcionáře ${ }^{2}$ - kdyby jen proto, že poukazuje na skutečnost, že hlavním nepřítelem všech konzervativců je čas. Čas se už každopádně pohyboval př́liš rychle pro reakcionáře, kteří se proto snažili posouvat hodiny nazpět; pohyboval se však př́liš rychle rovněž pro konzervativce status quo a reformní konzervativce, které nevyhnutelně předbíhaly změny, jež čas přinášel. S tímto na mysli nebude od věci poznamenat, že v Británii na konci 18. a na začátku 19. století zřejmě nepředstavoval čas př́liš velký problém. Konzervativní vlády byly bezpečně usazeny u moci desítky let (1784-1830) a podnikly rozhodné kroky, aby zablokovaly jakékoli politické změny, jež byly ve všech svých variantách spojovány s myšlenkami Francouzské revoluce. S podobným odporem se setkávaly sociální změny související s industrializací nebo se vzestupem ambicí vzdělaných a majetných tříd. V mezinárodních záležitostech mezitím Británie spolupracovala na ustavení nové rovnováhy moci po pádu Napoleona v roce 1815, rovnováhy, jež se zakládala na omezení Francie a kterou se Británie snažila udržet až do roku 1848. Jestliže však Prusko, Rakousko a Rusko interpretovaly uspořádání z roku 1815 jako ustavení sociálního řádu, který měl v mezinárodním měřítku předcházet revoluci, britští konzervativci takovému pojetí odporovali, at' už si mysleli o hrozbě revoluce doma cokoli. Britské mezinárodní závazky, vyplývající z dohod uzavřených roku 1815, se měly podle nich omezovat na dohled nad dodržováním teritoriálních smluv a na jejich vynucování. ${ }^{3}$

\section{Britský konzervatismus a zahraniční politika}

V jádru britského a vlastně i evropského konzervatismu stála postava Edmunda Burka, jehož Reflections on the Revolution in France [Úvahy o revoluci ve Francii], vydané v listopadu 1790, obsahovaly rané varování před skutečnou povahou událostí, které tam právě probíhaly. ${ }^{4}$ Burke byl vedoucím představitelem whigů, který se dříve stavěl za práva Američanů, Irů a Indiánů, v rámci - jak doufal - budoucí volně obchodující a blahodárně působící Britské říše, jíž se bude vládnout v souladu s principy slušnosti, zakládající se

1 Schumann, Hans-Gerd: The Problem of Conservatism. Some Notes on Methodology. Journal of Contemporary History 13, 1978, s. 803-817, 807. Další rozsáhlou diskusi k tomuto tématu viz Allen, David Y.: Modern Conservatism: The Problem of Definition. The Review of Politics, 43, č. 4, ř́jjen 1981, s. 581-603.

2 Epstein, Klaus: 'Introduction', The Genesis of German Conservatism. Princeton 1966.

3 Viz Holbraad, Carsten: The Concert of Europe. London 1970, Část II, Kap. 1.

4 O Burkovi existuje bohatá literatura. K jeho myšlení s ohledem na mezinárodní záležitosti viz Empire and Community. Edmund Burke's Writings and Speeches on International Relations. Eds. D. P. Fidler - J. M. Welsh, Boulder 1999; Schumann, Hans-Gerd: Edmund Burkes Anschauungen vom Gleichgewicht in Staat und Staatensystem. Mit einer Edmund Burke-Bibliographie. Meisenheim am Glan 1964. První práce obsahuje dlouhý hodnotný výtah z Burkových klíčových děl. 
na tradičních britských zákonech, zvyklostech a praktikách. Jeho nekompromisní útok na Francouzskou revoluci proto přišel tak trochu jako blesk z čistého nebe. Thomas Jefferson po přečtení Reflections napsal, že je více překvapen revolucí v Burkovi než revolucí ve Francii. ${ }^{5}$ Burke však upozorňoval své přátelé z řad whigů, že Francouzská revoluce se v ničem nepodobá Slavné revoluci z roku 1688 v Británii. Tehdy Britové nejen napravovali kazy své starobylé konstituce, ale snažili si uchovat své tradiční principy. Francouzi na druhé straně upadli nyní do stavu šílenství a zamýšlejí vše zničit, nivelizovat společnost a vytvořit nový řád založený na abstraktních principech. Ty představovaly hrozbu všem národům, nákazu, která by podryla zdraví politického organismu evropského společenství. Burke správně předvídal, že se Francie, najednou militarizovaná a opírající se o revoluční principy, stane hrozbou pro Nizozemí, a tím i pro národní bezpečnost Británie a pro celou evropskou rovnováhu moci; neměl však na mysli ani tak mezinárodní vztahy a zahraniční politiku jako ideologickou hrozbu vycházející z Francie. Britští radikálové, včetně jeho někdejších kolegů, whigovských poslanců v parlamentu, se chopili věci „lidských práv“. To ohrožovalo britskou konstituci i britský způsob života a představovalo zákeřný domácí problém. Burke proto požadoval, aby se s novým francouzským režimem nesjednával diplomatický kompromis, ale aby byl vymýcen ozbrojenou intervencí. V roce 1791 ho francouzští émigrés žádali o radu, a dokonce k němu vyslali svého stálého zástupce. On sám k nim naopak poslal svého syna Richarda, aby jim pomohl budovat ozbrojené síly. Sir Gilbert Elliot to komentoval následovně: „Burke je sám o sobě určitou mocností ve státě. A nebude ani př́lišným přeháněním říci, že je určitou mocností v Evropě. “6 Jeho křižácké tažení proti Francouzské revoluci vyvrcholilo v jeho posledním slově k této události ve Four Letters on a Regicide Peace [Čtyři dopisy o královražedném míru], napsaných v letech 1796-1797. V těchto dopisech prohlásil: „Jsme ve válce se systémem, který je svou podstatou nepřátelský ke všem ostatním vládám... V této válce jsme navzdory jakékoli válečné doktríně. " Proto zde nemělo smysl vyjednávat s vládci této revoluční Francie o nějaké rovnováze moci; byl to „žargon, jemuž nemohli rozumět ani s pomocí tlumočníka“. ${ }^{8}$ Válka proti Francii byla „občanskou válkou... mezi př́ivrženci starobylého občanského, morálního a politického řádu a sektou fanatických a ctižádostivých ateistů, kteří zamýšleli to vše změnit“. ${ }^{9} \mathrm{~A}$ tak musel být francouzský režim rozdrcen a vykořeněn: „...musí být zničen... těmi či oněmi prostředky, a síly, které se mu postaví, by měly být určitou analogií sil a ducha, které tento systém uplatňuje, a určitým způsobem se jim podobat... Jedním slovem, s touto republikou nemůže koexistovat nic nezávislého. "10 Burke, krátce řečeno, požadoval ideologickou válku s novou republikou, a to na život a na smrt. Britská vláda na druhé straně viděla pouze potřebu zůstat neutrální nebo vyjednávat diplomaticky. Toryovský premiér William Pitt se ve skutečnosti sešel s Burkem, aby si

5 Citováno v: The Papers of Thomas Jefferson, Ed. J. P. Boyd. Sv. XX. Princeton 1982, s. 391.

6 Citováno v: Empire and Community, str. 33.

7 Tamtéž, s. 35.

8 Tamtéz.

9 Tamtéz.

10 Tamtéz. 
vyslechl jeho rady, a podle Elliota ,je vesměs přijal velmi trpělivě a srdečně“ . ${ }^{11}$ Burke však natolik nedůvěřoval britské vládě, že tř̌i dny před svou smrtí - zemřel 9. července 1797 - požádal, aby byl pohřben „na neznámém a neoznačeném místě a odděleně od svého syna, ženy a bratra - kvuili francouzským revolucionář̃m “. Nechtěl, aby jakobíni znesvětili jeho hrob, kdyby jim Anglie padla do rukou. ${ }^{12}$

Britská vláda vedená Pittem však doufala, že se účasti na událostech v Evropě vyhne. Ještě 7. listopadu 1792 ministr zahraničí lord Grenville prohlašoval, že pokud Británie zůstane v cizině „zcela a naprosto stranou“, bude se moci soustředit na předcházení jakékoli vnitřní krize. ${ }^{13} \mathrm{~V}$ dubnu 1792 jeden z jeho podsekretářů mohl napsat: „Tak či onak lze doufat, že náš obranný př́kop zaplněný slanou vodou nás může ochránit a já pokládám možnost, že se zapleteme do války tohoto druhu, pokud to lze předvídat, za nepravděpodobnou nahodilost. "“14 Nicméně Francouzi vyhlásili 1. února 1793 válku a na Pittovi zůstalo, aby to vysvětlil parlamentu: „Ve jménu svobody neakceptují žádný jiný model vlády než ten, který je v souladu s jejich vlastními názory a idejemi, a všichni lidé se v každé části světa musí z ústí hlavní jejich kanónů poučit, jak propagují svůj systém. " ${ }^{15} \mathrm{O}$ několik měsíců později řekl: „V tom, co se nazývá vládou mas, nejsou mnozí, kteří vládnou málu, ale několik málo, kteří vládnou mnohým. Je to odrůda tyranie, která k ubohosti svých poddaných přidává urážku, když své vlastní svévolné dekrety stylizuje jako hlas lidu a akty útlaku a krutosti ospravedlňuje záminkou, že jde o vůli národa." ${ }^{16}$

Ale souhlasil by toryovský vůdce (Pitt) s vykořeněním tohoto systému, jak k tomu radil Burke (podle Epsteinova klasifikačního systému v zahraničních záležitostech spíše „reakcionáŕ“ než prostý konzervativec; v domácí politice byl přinejlepším konzervativcem statu quo)?

Jakmile vypukla válka, britské válečné cíle zahrnovaly osvobození Nizozemí, zničení francouzské flotily a francouzských námořních základen a ovládnutí francouzských kolonií. Henry Dundas, Pittův ministr války, pokládal za jeden z válečných cílů rovněž ukončení „anarchie ve Francii“, ačkoli nejen k osvobození Nizozemí, ale i k svržení francouzské vlády by bylo zapotřebí evropské pomoci. ${ }^{17}$ Obtíž spočívala v tom, že evropské mocnosti se bud' z války stáhly, nebo neustále zaznamenávaly porážky. Později pak požadovaly obrovskou finanční podporu, aby pokračovaly v boji. Mezitím v roce 1805 Pitt během vyjednávání s Ruskem nastínil plán evropského uspořádání založeného na rovnováze moci, který zahrnoval rozšíření Holandska a Piemontu, s Pruskem pevně usaze-

11 Podle Elliota: „Burke mu [Pittovi] dal určité politické instrukce, a to velmi zdvořile a srdečně, ale s autoritou staršího a mnohem poučenějšího státníka; a přestože nikdo nikdy nedal na Burkovy rady zcela ve všem, přece jen často, nebo spíše vždy, sděloval velmi důležité a užitečné věci, z nichž určitá část se uchytila a byla ku prospěchu. Pitt si to vše vyslechl velmi trpělivě a vstřícně.“ Tamtéž, pozn. 307, s. 331.

12 Citováno v O’Brien, Conor C.: The Great Melody. London, 1992, s. 587.

13 Citováno v Duffy, Michael: British Diplomacy and the French Wars 1789-1815. In: Britain and the French Revolution 1789-1815. Ed. T. H. Dickinson. Basingstoke 1989, s. 128-145, s. 128. (Tato kniha zůstává nejlepším sborníkem esejů o Británii a Francouzské revoluci.)

14 Tamtéž.

15 Parliamentary History XXX, s. 278 (1. únor 1793).

16 Parliamentary History XXX, s. 901-902 (6.-7. květen 1793).

17 Duffy, M.: British Diplomacy, s. 130. 
ným v Porýní a s Rakouskem hrajícím hlavní roli v Itálii. Význam britských zámořských koloniálních zisků byl snížen a restaurace Bourbonů se stala v „dohodě, k níž se mělo nyní dospět a která v žádném případě nemohla ospravedlňovat prodlužování války“, jen druhořadým cílem, pokud se mělo dosáhnout míru ve shodě s rovnováhou moci, o níž se jednalo s Rusy. ${ }^{18}$

Svržení francouzského režimu tedy nikdy nepatřilo mezi prvořadé britské cíle. Proto také Británie nikdy oficiálně neuznala hraběte z Provence za krále Francie. Pomoc francouzským royalistům při budování armády a při jejich povstáních ve Francii měla sloužit jen k oslabení republikánského válečného úsilí. Británie dávala peníze a najímala špióny, aby vytvořila zpravodajskou sít na kontinentu. Potlačení revoluce by konec konců zabránilo rozvracení celé Evropy a restaurace legitimního krále by byla nejlepší zárukou trvalého míru. Na druhé straně však byli francouzští royalisté nesmiřitelně rozdělení mezi stoupence absolutismu a konstituční monarchisty a Grenville byl přesvědčen, že o obnovení absolutismu či feudalismu nemůže být ani řeči. Británie si místo toho přála novou dědičnou konstituční monarchii, která by chránila soukromé vlastnictví, ačkoli podle Grenvillova názoru se ani francouzští konstitucionalisté vypuknutím revoluce v ničem nepoučili. A co hůr̆, jak mu bylo sděleno, přestože se obě větve francouzských monarchistů navzájem nenáviděly, ještě více nenáviděly Brity - „bylo by mnohem snadnější sjednotit všechny Francouze ve společném odporu k Británii než v odporu k revoluci“. Britové tak jako tak chtěli omezit hranice Francie a obklopit ji nepřátelskými státy, které by byly silnější než dosud. Chtěli si rovněž přivlastnit francouzské kolonie a zničit francouzskou flotilu. Za jejich podporu bylo proto nutno platit vysokou cenu i pro francouzské vlastence bojující proti revoluci.

Francouzští kontrarevolucionáři byli v samotné Francii v každém případě slabí a jejich úsilí v Toulonu, ve Vendée, v Quiberonu i kdekoli jinde neustále selhávalo kvůli nedostatečné lidové podpoře. Je pravda, že britské úplatky vynesly royalisty ve volbách v roce 1797 do parlamentu, ale zvolení poslanci nijak netoužili přizpůsobit se britským válečným cílům a v každém případě je vypudil Napoleonův „kouř z kartáčů“. Nakonec, po dalším neúspěšném royalistickém povstání v roce 1800, Castlereagh jakožto ministr války vetoval jakoukoli další pomoc royalistům a Britové přijali strategii financování kontinentálních mocností. ${ }^{19}$ Británie rovněž intervenovala ve Španělsku, ale klíčem k jejímu konečnému úspěchu bylo Napoleonovo odmítání uzavřít mír, dokud ho v roce 1814 nesvrhla čtvrtá koalice. Po Vídeňském kongresu byla proto do dohody z roku 1815 vtělena většina návrhů Pittova plánu z roku 1805, který předpokládal britskou dominanci na moři a ustavoval rovnováhu moci, zahrnující rozšířené Holandsko a Piemont, pruské vlastnictví Porýní, Rakousko jako vedoucí mocnost v Itálii a ruský zábor Polska. Rakousku rovněž připadlo předsednictví v novém Německém spolku. Druhá pařížská smlouva mezitím zajistila Francii její hranice z roku 1792; musela ale zaplatit reparace a strpět vojenskou okupaci. Její největší nepřátelé pak podepsali Čtyřstrannou alianci, jež měla zaručovat dodržování těchto smluv i přes případné obnovení bonapartistického ohrožení.

18 Tamtéž, s. 133.

19 K britským pochybnostem ohledně francouzských royalistů viz diskusi v Duffy, M.: British Diplomacy, s. $134-136$. 
Británie doufala, že v důsledku toho se bude moci stáhnout z evropských záležitostí. Přesto ji už za velmi krátkou dobu revoluční nepokoje a bouře opět postavily před otázku, zda je či není v britských konzervativních zájmech zasahovat do domácích záležitostí národních států.

Není třeba dále rozvádět popis „Kongresového systému“ z let 1815-1822. ${ }^{20}$ Postačí říci, že když si Rakousko, Prusko a Rusko vyhradily právo intervenovat v domácích záležitostech jiných států i bez jakéhokoli pozvání podle Opavského protokolu z roku 1820, Britové s tím vehementně nesouhlasili. Ve známém státním dokumentu z 5 . května 1820 ministr zahraničí Castlereagh trval na tom, že Čtyřstranná aliance z roku 1815 byla namířena jen proti Francii, kdyby opět upadla pod bonapartistickou vládu nebo jinak přímo ohrožovala bezpečnost Evropy: „U této Aliance stejně jako u všech jiných lidských dohod platí, že nic s větší pravděpodobností neoslabí, nebo dokonce nezničí její skutečnou užitečnost než jakákoli snaha posunout její povinnosti a závazky za sféru, k níž ji opravňuje její původní koncepce a dohodnuté principy: Byl to svaz pro opětovné dobytí a osvobození velké části evropského kontinentu z vojenského područí Francie, a když přemohl dobyvatele, prosadil stav územního vlastnictví, jak byl dohodnut mírovou smlouvou pod záštitou Aliance. Ta však nikdy nebyla zamýšlena jako svaz pro vládu nad světem nebo pro dohled nad vnitřními záležitostmi jiných států."21

Castlereagh v oběžníku z 19. ledna 1821 rovněž tvrdil, že principy, o něž se opírá intervence, „nemohou být bezpečně přijaty jako systém mezinárodního práva“. V rukou „méně blahodárných monarchư“, než jsou ti, kteří právě vládnou v Evropě, by mohly vést $\mathrm{k}$ neustálým intervencím, takže je nelze „smířit ani s obecným zájmem, ani s účinnou autoritou a důstojností nezávislých panovníkư “.22 A v Dolní sněmovně v roce 1821 prohlásil, že „nemůže uznat principy, které opravňují jeden stát zasahovat do záležitostí jiného jen proto, že v jeho vládě mohly být provedeny změny takovým způsobem, který by první stát neschvaloval“. ${ }^{23}$

Britská doktrína intervence proto kladla dưraz na bezprostřední a přímé ohrožení národní bezpečnosti ze strany Francie spíše než na udržení sociálního nebo politického řádu. Castlereagh ve svém státním dokumentu odmítl jednat na základě abstraktních a spekulativních principů předběžné opatrnosti; jednal by jen tehdy, „kdyby evropský systém ohrožovalo aktuální nebezpečí““. ${ }^{24}$ Ve svém oběžníku z ledna 1821 zdůraznil, že intervenci lze ospravedlnit jen v případě států, „u nichž je bezprostředně vážně ohrožena jejich bezpečnost nebo bytostné zájmy vnitřními úkony jiného státu“. ${ }^{25}$ Avšak to mělo být

20 Nejnovější a vynikající popis tohoto systému viz v Jarett, Mark: The Congress of Vienna and its Legacy. London and New York 2013.

21 Foundations of British Foreign Policy from Pitt (1792) to Salisbury (1902) or Documents Old and New. Eds. H. Temperley - L. M. Penson. Cambridge 1938, s. 54.

22 Citováno v Webster, Charles K.: The Foreign Policy of Castlereagh, 1815-1822. Britain and the European Alliance. London 1925, s. 321.

23 Hansard, 2. řada, sv. V., sl. 1256-7 (21. červen 1821).

24 Foundations, s. 63.

25 Webster, Ch. K.: The Foreign Policy, s. 322. Srov. s. 283: „Veškerá spekulativní politika je mimo její kompetence. Nyní se [intervence] navrhuje jako prostředek překonání revoluce; ale dokud se tato revoluce 
vždy výjimkou spíše než pravidlem nebo obecným principem. Britská doktrína intervence proto vešla ve známost jako teorie „neintervence“.

Jiní konzervativní státníci zastávali podobný princip čistě teritoriálního konzervatismu. [Jinými slovy šlo jim o udržení územního uspořádání z roku 1815, nikoli o zachování tehdy ustanoveného politického a sociálního řádu.] Canning v roce 1823, kdy byl ministrem zahraničí, prohlásil s ohledem na kongres ve Veroně: „Byl jsem - a stále jsem - nadšeným stoupencem národní nezávislosti..."26 Při jiné příležitosti řekl: „Podle mne má platit pravidlo, že naše angažovanost se vztahuje jen ke stavu teritoriálního vlastnictví ustavenému v míru; $\mathrm{k}$ stavu záležitostí mezi národem a národem, nikoli... k vnitřním záležitostem nějakého národa.“27 Canning tak oponoval tomu, co nazýval „doktrínou evropské policie“. ${ }^{28}$ Stejný druh kritiky zazníval z úst jiného budoucího premiéra, Sira Roberta Peela, který v Dolní sněmovně v roce 1823 protestoval proti „doktríně zastávané takzvanou Svatou aliancí, doktríně jejího práva zasahovat do svobody národů zřízením jakési evropské policie, která měla bránit úspěšnému završení revoluce, at̉ už by vypukla kdekoli a za jakýchkoli okolností“. ${ }^{29}$ Místo toho prosazoval princip, že „každý stát je suverénní a nezávislý a je jediným soudcem reforem a modifikací, které jsou nezbytné pro jeho vládu“. Ostatní státy si mohly v důsledku toho stěžovat, že utrpěly újmu, ale tato újma „by neměla být imaginární či spekulativní - měla by být takové povahy, že by ji jasně a hmatatelně viděl a cítil každý člověk “. ${ }^{30}$

O Canningovi se má obecně za to, že zašel dále než Castlereagh a že byl odhodlán jednou pro vždy rozvázat spojenectví s evropskými státy a skoncovat s kongresovým systémem. Tento názor sice přehání, ale Canningova rétorika může snadno budit tento dojem. Už v době kongresu v Aix-la-Chapelle v roce 1818 se obával, že evropské kongresy „nás hluboce zatáhnou do všech aspektů politiky na Kontinentu, kdežto naší správnou politikou vždy bylo nevměšování s výjimkou velkých mimořádných událostí, ale pak s impozantní silou“. ${ }^{31}$ Jeho cílem bylo, aby Británie ani nepomáhala despotismu na Kontinentu a nezvětšovala ho, ale ani nevnucovala Evropě svůj vlastní konstituční systém. Měla by „zaujímat neutrální postavení nejen mezi soupeřícími národy, ale i mezi konfliktními principy“. 32

Byl rozdíl mezi britskými a evropskými konzervativci ohledně zahraniční politiky opravdu tak velký? Castlereagh v roce 1820 silně schvaloval rakouskou invazi do Neapole - třebaže spíše podle smlouvy z roku 1815 než pod záštitou Aliance. A ve své poslední

neprojeví v nějaké zřetelnější a... materiálně nezaútočí na nějaký jiný stát - Anglie nebude ochotna s ní bojovat."

26 Temperley, Harold: The Foreign policy of Canning, 1822-1827. London 1925, s. 464-465.

27 Phillips, Walter A.: The Confederation of Europe, a Study of the European Alliance, 1813-1822 as an Experiment in the International Organization of Peace. London 1914, s. 275.

28 Hansard, 2. řada, sv. VIII, sl. 1465 (30. duben 1823).

29 Hansard, 2. řada, sv. VIII, sl. 1419-20 (29. duben 1823).

30 Hansard, 2. řada, sv. VIII, sl. 66 (4. únor 1823).

31 Memoirs and Correspondence of Viscount Castlereagh, Second Marquess of Londonderry. Ed. C. Vane. Sv. XII. London 1848-53, s. 56-57.

32 Hansard, 2. řada, sv. VIII, sl. 1523 (30. duben 1823). 
řeči v Parlamentu v roce 1821 prohlásil k poslancům: „Odsuzuji doktrínu, že poddaní vlád, kteří se netěší zastupitelskému systému, mají právo odhodit svou loajalitu a uchýlit se ke zbraním, aby ho získali. “33 To byl i Metternichův názor a Castlereagh navíc sdílel s tímto rakouským státníkem přesvědčení, že všechny revoluce v Evropě jsou řízeny nějakým tajným výborem, který měl podle Metternicha sídlit v Paříži: „Dnes v cizině dochází ke spiknutí, které ohrožuje existenci jakékoli zákonné vlády. Pokud je tomu tak, není připraven říci, do jaké míry můžeme přestat obhajovat obecné principy, např́klad ty, které jsou obsaženy v prohlášeních panovníků, abychom získali prostředky, jak předcházet zlům, jimiž jsou ohroženy všechny vlády. V celé Evropě se projevil systém všeobecné subverze a jedna revoluce se stávala prostředkem zrození další." ${ }^{44}$ Jisté je, že jakmile se v roce $1830 \mathrm{~s}$ vypuknutím revoluce nejprve ve Francii a poté v Belgii přiblížilo revoluční dění k britským břehům, lord Aberdeen požadoval, aby mocnosti spojeným úsilím ukončily anarchii v Nizozemí. Sir Richard Vyvyan dokonce řekl poslancům Dolní sněmovny, že intervence by se měla stát spíše pravidlem než výjimkou. Přesto to byl stále především strach z francouzské agrese a z evropské války spíše než obava z revoluce per se, který v Británii získával podporu nějaké doktríně intervence. ${ }^{35} \mathrm{Na}$ druhé straně by kritici až do roku 1848 mohli poukazovat na britskou politiku na Iberském poloostrově jako na doklad toho, že rovněž Británie vojensky intervenovala, aby udržela probritské režimy, zejména v Lisabonu. Británie ve skutečnosti vojensky zasahovala v Portugalsku, aby podpořila portugalský konstitucionalismus (a liberalismus, máme-li věřit Palmerstonovi), v letech 1826, 1834 a 1847. Podle slov Rogera Bullena: „V Berlínské konvenci z října 1833, podepsané třemi mocnostmi (Rakouskem, Ruskem a Pruskem - pozn. autora), se právo intervenovat zakládalo výlučně na právu nezávislých panovníků obrátit se na spřízněné monarchy s prosbou o pomoc. (Britské a francouzské námitky vylučovaly od roku 1822 možnost požádat o intervenci unilaterálně ve prospěch žádosti Aliance - pozn. autora.) Když v roce 1834 Velká Británie a Francie reagovaly na prosby vlád Portugalska a Španělska o pomoc, jednaly na západě podle téhož principu. Čtyřstranná aliance z dubna 1834 a její Dodatečné články z července byly západním ekvivalentem Berlínské konvence. $\mathrm{V}$ třicátých letech už mezi mocnostmi neexistovala, pokud šlo o právní základ intervence, žádná zásadní neshoda.“36

Byl zde také př́ípad Irska. ${ }^{37}$ Lišila se britská politika v této zemi tak mnoho od, řekněme, habsburské politiky v Lombardsku-Benátsku nebo v Uhrách? Odpověd' zní ano, skutečně se lišila. V roce 1789 Irsko prožívalo ekonomický rozmach, jeho parlament získal významné pravomoci nezávislé na Velké Británii a očekávalo se, že budou uzákoněny další sociální a politické reformy. Ostrov se stal problémem až během americké války,

33 Hassal, Arthur: Viscount Castlereagh. London 1908, s. 220.

34 Hansard, 2. řada, sv. V, sl. 1257 (21. červen 1821).

35 Holbraad, Carsten: The Concert of Europe. Canberra 1971, s. 120.

36 Bullen, Roger: The Great Powers and the Iberian Peninsula, 1815-1848. In: Europe's Balance of Power, 1815-1848. Ed. A. Sked. London and Basingstoke 1979, s. 54-78, 56.

37 Mezi spoustou prací o Irsku viz Elliott, Marianne: Ireland and the French Revolution. In: Britain and the French Revolution. Ed. T. H. Dickinson. s. 83-101; Foster, Robert F.: Modern Ireland. 1600-1972. London 1989. 
protože v té době se identifikoval s americkými kolonisty, jejichž spory se zpupným westminsterským parlamentem odrážely jeho vlastní. Na druhé straně mu Westminster v letech 1782-1783 propůjčil plnou parlamentní svrchovanost. Potíž spočívala v protestantské převaze episkopální pozemkové elity, která ovládala chod parlamentu a využívala ho ke službě svým vlastním zájmům a nyní se distancovala od vzestupujících protestantských středních tříd stejně jako od katolíků a disenterů bez volebního práva. To nebylo moudré, nebot' během americké války se tito lidé organizovali v dobrovolných milicích, aby chránili svou zemi. Pod vlivem Francouzské revoluce a pojednání The Rights of Man [Práva člověka] od Thomase Paina, které v té době vyšlo v Irsku, kolovalo mezi lidmi a získalo si širokou čtenářskou obec, se tito dobrovolníci proměnili v radikální společnost nazvanou Sjednocení Irové. Tato nejprve diskusní společnost čelící vládním represím a rostoucímu rozkolu mezi ulsterskými protestanty a katolíky, s nadějí na francouzskou podporu (francouzská flotila vplula v roce 1795 do Bantry Bay, aniž se setkala s odporem, ale byla kvůli špatnému počasí nucena se stáhnout), zosnovala v roce 1798 poněkud nekoordinované povstání, které bylo poraženo. Mezitím Pittova vláda, znechucená protestantskou elitou, vnutila v roce 1793 Irskému parlamentu volební reformy, načež ho úplně zrušila a v roce 1800 Zákonem o Unii sjednotila Irsko s Velkou Británií. Od té doby zasedali irští poslanci v Dolní sněmovně. Po roce 1815 se stal přední irskou osobností Daniel O’Connell, který byl v doplňovacích volbách v roce 1828 zvolen poslancem za hrabství Clare s programem zrušení Unie a emancipace katolíků, jež byla uzákoněna v roce 1829 . K tomuto datu získali katolíci v celém Spojeném království volební právo. Činnost konzervativců nespočívala jen v prosté represi. Pravda, katolíci museli se svou nadějí na blízkou emancipaci čekat dlouho, ale spíše kvůli králi a protestantské elitě než kvůli Pittovi a ostatním konzervativcům; pravda, Spojení Irové museli být nakonec potlačeni, i když byli několik let tolerováni. Na druhé straně konspirace s nepřítelem v době války byla vážnou záležitostí a Irsko bylo pro bezpečnost Británie životně důležité. Nakonec Irsko zaujalo v rámci Unie své místo spolu se Skotskem a Walesem, bylo zastoupeno ve Westminsteru a katolíci dostali volební právo. Volby probíhaly svobodně a pravidelně jako v Anglii, Walesu a Skotsku. Irsko by proto jen stěží mohlo představovat obdobu Lombardska-Benátska či Uher.

\section{Domácí konzervatismus}

Navzdory trestním opatřením přijatým proti radikálům v dlouhém období dominance konzervativců v Británii během éry Francouzské revoluce a napoleonských válek a po nich je zde vhodné citovat předního odborníka na britský radikalismus, profesora Dickinsona, který napsal, že „lze tvrdit, a to docela přesvědčivě, že radikálové byli poraženi silou argumentů jejich protivníků a konzervativním klimatem, nikoli pouze jen přijetím represivních opatření a s pomocí pořádkových sil“. Citát pochází z jeho knihy Liberty and Property. Political Ideology in eighteenth century Britain [Svoboda a vlastnictví. Politická ideologie v Británii 18. století]. ${ }^{38} \mathrm{~V}$ ní poukazuje na řadu autorů - Jonaha Tuckera,

38 London 1977, s. 272. O ideologii konzervatismu v Británii viz následující: Gunn, John A. W.: Beyond Liberty and Property. Kingston and Montreal 1983; Clark, Jonathan C. D.: English Society 1688-1832. Cambridge 
Francise Basseta, Soama Jenynse a lorda Riverse, kteří bránili stávající britskou konstituci s jejím systémem brzd a rovnováh - jak to chápali oni - proti svévolnému uplatňování síly jakoukoli součástí panující moci. Zdůrazňovali souvislost mezi politickou stabilitou a vlastnictvím; odmítali jakoukoli představu, že poslanci by měli být pouhými delegáty svých voličů; ospravedlňovali „praktické zastoupení“ občanů bez volebního práva; podporovali př́ítomnost vládou dosazených lidí v Dolní sněmovně; a byli přesvědčeni, že poslanci by měli reprezentovat spíše národní než stranické nebo místní zájmy. Přesto se většina jejich názorů zakládala na čistě praktických důvodech, což podněcovalo další, aby rozvíjeli soudržnější nebo více ideologicky ucelené konzervativní názory. Jejich nejslavnější výklad samozřjejmě pochází z Burkových Reflections on the Revolution in France, avšak profesor Ian Christie ve svých pozoruhodných Fordových přednáškách z let 1983-1984 pokládal za významného Burkova předchůdce Williama Paleye. ${ }^{39}$

Paleyova kniha The Principles of Moral and Political Philosophy [Principy morálni a politické filosofie] vyšla v roce 1785 a po čtyřech dotiscích se v roce 1790 dočkala druhého, revidovaného vydání. Asi rok po svém prvním vydání byla přijata jako standardní zkušební text na Cambridgeské univerzitě, takže nevyhnutelně ovlivňovala dorůstající generaci politiků. Po roce 1789 určitě poskytla argumenty odpůrcům revoluce.

Paley napsal, že politická poslušnost je, vezmeme-li v úvahu pouhou fyzickou sílu populace, nakonec dobrovolná. Nicméně lidé zůstávají většinou poslušní, což je fakt, který Paley připisoval zejména starým zvykovým normám. To podle něj nebylo nic překvapivého, nebot’ lidé obvykle ze stejných důvodů uplatňovali svá vlastnická práva. Pokud jde o tyto zvykové normy, radí k opatrnosti, nebot inovace vždy vyvolávají nestabilitu. Paley, odmítající jakoukoli smluvní teorii týkající se původu vlády jako fiktivní, připisoval vznik občanské společnosti účelnosti nebo okolnostem, tj. historické evoluci, ačkoli okolnosti rovněž připouštěly právo bouřit se. Stejně jako radikálové i Paley pohlížel na občanskou svobodu jako na absenci právních omezení, s výjimkou těch, které si vynucoval veřejný zájem. Občanská svoboda však vyžadovala instituce a zvyklosti, které by ji chránily a předcházely ohrožení individuální svobody. Mezi ně patřila vláda zákona, rozdělení moci, zdanění jen prostřednictvím zastoupení, svobodné a nezmanipulované volby a veřejná kontrola armády. Proto věřil, že nejlepší je britská „smíšená vláda“ krále, aristokracie a poslanců. Na rozdíl od radikálů odmítal představu původní, dokonalé konstituce, která byla časem zkažena, a stavěl se proti srovnávání současné britské konstituce s nějakým spekulativním modelem, který byl dokonalý. Změna by měla postupně narůstat. Bránil současný volební systém s jeho zvýhodněním pozemkových vlastníků a bohatých, ale obhajoval zveřejnění parlamentních debat a postupů. Zastoupení, tvrdil, není přirozeným právem a vůbec, je právem, jen pokud slouží veřejnému dobru. Není ani tak důležité, kdo jsou zvolení poslanci, jako to, zda prosazují národní zájmy. Byl příznivě nakloněn ekonomickým reformám a přimlouval se za redukci patronátu koruny, ale obhajoval

1985; Schofield, Thomas P.: Conservative Political Thought in Britain in Response to the French Revolution. Historical Journal XXIX, 1986, s. 601-622.

39 Christie, Ian R.: Stress and Stability in Late Eighteenth Century Britain. Reflections on the British Avoidance of Revolution. The Ford Lectures, Delivered in the University of Oxford, 1983-1984. Oxford 1986. Následující diskuse o Paleyovi a Burkovi se přidržuje šesté kapitoly, „The Intellectual Repulse of Revolution“. 
účast vlády a zastoupení vládních „zájmư“ v obou sněmovnách parlamentu. Když psal o volbách v roce 1784, tvrdil: „Když se na to podíváme ze všech stran, současná reprezentace je i přes zmatky, v nichž nepopíratelně vězí, stále do té míry lidová, či spíše poslanci jsou natolik spojeni společenstvím zájmů a vášní s masami společnosti, že vůle lidu, je-li odhodlaná, trvalá a obecná, nakonec téměř vždy převáží. “40

Nejslavnějším konzervativním traktátem té doby a snad nejslavnějším vůbec jsou samozrrejmě Burkovy Reflections on the Revolution in France. Stejně jako Paley byl i Burke proponentem historického utilitarismu. Rovněž akceptoval teorii přirozeného práva, neměnného práva božského původu, které předcházelo právu pozitivnímu, vymezovalo povahu morální povinnosti a poskytovalo kritérium spravedlnosti v sociálním řádu. Částečný důkaz tohoto práva se odvozoval ze zjeveného náboženství a důraz na morální povinnost znamenal, že „práva“ by se neměla pojímat izolovaně. Navzdory těmto metafyzickým úvahám však Burke pokládal za reálný test institucí nikoli teorii, ale praktickou zkušenost či historii: „Měl byste se zabývat konkrétním člověkem, obyčejným lidským životem a lidským jednáním. “41 Podstatné je vědět, co se skutečně v minulosti stalo. Politické organizace se vyvíjely dlouhodobým procesem pokusu a omylu, v němž vždy probíhají jejich nezbytné modifikace. Různé politické komunity budou mít různé zkušenosti, a podstatné není to, aby byla zaručena jakákoli partikulární „práva“, ale stávající společenský systém, v němž řád, povinnost a spravedlnost byly sloučeny $\mathrm{v}$ nejlepších schopnostech jeho členů ve shodě s pravidly božského řádu. Žádný systém nemůže být dokonalý a všechny budou podřízeny budoucím evolučním změnám, ale hlavní rysy společnosti jsou ospravedlněny prostě už jen tím, že existuje. Přirozené právo se tak ztotožňuje s právem zvykovým.

Burke proto oponoval parlamentní reformě, nebot reformátoři „po nás chtějí... abychom dali přednost jejich spekulacím... před štastnou zkušeností této země s pěti stoletími rostoucí svobody a rostoucí prosperity“. ${ }^{42}$ Jak dále napsal: „Existuje řád, který drží věci pevně na svém místě; je stvořen pro nás a my jsme stvořeni pro něj. “"43 Jestliže je společnost vázána smluvními vztahy, není to něco, co by připomínalo nějakou obchodní smlouvu. „Je spoluúčastí na veškerém vědění, spoluúčastí na vší dovednosti, spoluúčastí na každé ctnosti a veškeré dokonalosti. A protože cílů takovéto společnosti nelze dosáhnout ani v mnoha generacích, stává se partnerstvím nejen těch, kdo právě žijí, ale všech živých, zemřelých a dosud nenarozených. " ${ }^{44}$ Zákony, které se vyvíjely po generace, se vzhledem $\mathrm{k}$ omezeným lidským schopnostem nejvíce přibližovaly zákonům božím. At už Burkovy názory na přirozené právo a zvykové normy obstojí, či nikoli, a at už jakkoli přeháněl blahodárnost ancien régime ve Francii a nemohl pochopit, že v roce 1688 ve skutečnosti skončil proces, který započal v roce 1641 popravou britského panovníka, faktem zůstává, že Burke v roce 1790 téměř jako jediný správně předvídal krvavou budoucnost

40 Citováno v Christie, I. R.: Stress and Stability, s. 164.

41 Tamtéž, s. 165.

42 Tamtéz̆, s. 168.

43 Tamtéž, s. 169.

44 Tamtéz. 
běhu událostí ve Francii a v Evropě: „Absolutní monarchie skomírala... Veškeré zápasy, veškeré rozbroje vyvstaly až potom, když byla před zřízením vzájemně se vyvažující moci dána přednost despotické demokracii. Triumf vítězné strany byl triumfem nad principy britské konstituce. " ${ }^{45}$ Většina whigů ${ }^{46}$ a dokonce předních disenterů - i když určitě ne Paine - během několika let přijala Burkovo stanovisko.

Měli bychom však poznamenat, že také Burke uznával právo na vzpouru. Ve skutečnosti existovalo pět specifických případi̊ vzpoury, v nichž by s ní souhlasil. ${ }^{47}$ Ale vzpouru bylo možno ospravedlnit jen jako poslední východisko a nikoli abstraktními, nýbrž konkrétními důvody: „Doba, události a okolnosti nabídnou řešení. Moudrého přiměje k jednání vážnost situace, vášnivého citlivost na útisk, šlechetného opovržení a pobouření nad hrubou mocí v nehodných rukou, statečného a smělého touha čestně obstát v nebezpečí při obraně správné věci. “48 Jakožto whig obhajoval Slavnou revoluci v návrhu parlamentního projevu k Jiřímu III. v roce 1777: „Sire, váš trůn nemůže stát bezpečně na principu nepodmíněné podřízenosti a pasivní poslušnosti.“ Pak následovala jeho interpretace událostí z let 1688-1689: „Lidé v té době znovu vstoupili v držbu svých původních práv, a nebylo to proto, že by nějaké pozitivní právo autorizovalo to, co tehdy dělali, ale protože svoboda a bezpečnost poddaných, původ a příčina všech práv, vyžadovaly postup jim nadřazený a mající přednost. $\mathrm{V}$ tomto... období byla platnost litery zákona pozastavena ve prospěch podstaty svobody." ${ }^{49}$

Ve Francouzské revoluci nešlo na rozdíl od Slavné revoluce v Anglii v roce 1688 o otázku svobody, ale o údajnou svrchovanost lidu. Jeden Burkův žák formuloval v roce 1793 problém takto: „Dnešní doktríny, jež ctí absolutní, neomezenou a neomezitelnou svrchovanost lidu, nehlásají nic jiného než přesun despotismu z vladaře na národ - ničivý a ohavný princip zůstává stále týž. Očekávat, že hromadný despotismus přinese občanskou svobodu, je totéž co myslet si, že hromadná hloupost přinese opravdovou moudrost." "50

Burke sám na Painova Práva člověka neodpověděl, ale v roce 1791 tak s jeho souhlasem učinil mladý irský právník William Cusac Smith v práci nazvané Rights of Citizens [Práva občanů]. Když Smith obhájil zvykové právo a rozbil argumentaci ve prospěch přirozených

45 Tamtéž, s. 174.

46 Dobré shrnutí jejich zkušeností během Francouzské revoluce viz Derry, John: The Opposition Whigs and the French Revolution, 1789-1815. In: Britain and the French Revolution. Ed. T. H. Dickinson, s. 39-59. K náboženské otázce viz Christie, Ian R.: Stress and Stability, kap. VII, v níž píše (s. 201-202): „Člověk, který dospívá nebo doufá, že dospívá, jakýmikoli prostředky k tomuto pocitu mravní čistoty a smíření se sebou a se světem, je ipso facto nezainteresován na sekulární revoluci. To bylo snad podložím úvah, které vedly většinu wesleyánských metodistů (a vlastně i jiných evangelikálů) k tomu, aby se v revolučním věku vyhýbali politickému radikalismu." Srov. Wearmouth, Robert F.: Methodism and the Common People of the Eighteenth Century. London 1945, s. 262: „Zasahoval-li vliv metodistů nejnižší vrstvy společnosti, zhruba splýval s idejemi a principy občanského řádu, mravní integrity a slušnosti. Pokud se týká metodistů, král a vláda se nemuseli obávat žádných povstání a revolucí; stáli na straně práva a pořádku..."

Cobban, Alfred: Edmund Burke and the Revolt against the Eighteenth Century. London 1929, s. 55, 100. 
práv, přistoupil dokonce k tvrzení, že nerovnosti, které se uchovávají ve společnosti a které jsou chráněny občanskými zákony, jsou naprosto přirozené: „Společenské regulace vyvažují nerovnost, která je dílem přírody, nebot ustavují rovnost, která je dílem konvence. Rovnost divocha je zmatení pojmů. Regulovaná a podřízená nerovnost je spravedlivým výtvorem, který poskytla př́íroda ve spolupráci s lidskými vášněmi a lidským rozumem. “51 Radikálové a levelleři si zkrátka přáli návrat ke zmatku divošské rovnosti. Na závěr Smith napadl konečný výsledek teorie přirozených práv - tyranii většiny. Na rozdíl od Burka se však projevil jako „nestydatý elitář““, když napsal: „Nemohu se přimět k tomu, abych zaníceně bazíroval na právech mnoha, když vím, že ctnostní jsou jen nemnozí. "52 Britští konzervativci by se na to nedívali jinak.

Dnes by se názory těchto lidí daly pokládat za samoúčelné. Ale profesor Christie nesouhlasí: „...závažnějším tématem konzervativního myšlení byl hluboce zakořeněný pragmatismus, který se přeléval do historického utilitarismu, zrozeného ze staletí dlouhé zkušenosti s povlovným vývojem anglického zvykového práva. Tato tradice živila instinktivní nepřátelství k násilnému nebo svévolnému výkonu autority bez ohledu na to, jaký je její zdroj, at’ už je to královský majestát, vojenská tyranie nebo efemérní většina. Konzervativní myšlení 18. století si spíše než vlády většiny cenilo konsensu... Jádrem tohoto konzervativního myšlení byla úcta $\mathrm{k}$ vládě zákona v občanské společnosti. Taková vláda zákona představovala přímý protiklad tyranské, svévolně prosazované politické moci a chápala se jako jediná záruka života, svobody a vlastnictví jednotlivce. V nárocích na ochranu zákonem si všichni lidé byli - nebo by si měli být - rovni. To však neopravňovalo požadavky rovnosti v jiných ohledech. Veškerá lidská zkušenost hovořila pro to, že rozdíly v nabývání majetku jsou v důsledku různých faktických vrozených schopností a povah různých lidí přirozené, nikoli nepřirozené. Rovnost před zákonem s sebou nenesla ani taková rovná politická práva, jako je všeobecné volební právo. Francouzská zkušenost po roce 1789 ve skutečnosti ukázala, že rovné volební právo, vedoucí k tyranii většiny, může zničit mnohem hodnotnější princip rovnosti před zákonem. V devadesátých letech 18. století tedy britští autoři a komentátoři shromažd’ovali poučení plynoucí z historie, z pragmatické zkušenosti a z užitečnosti, aby na jejich základě bránili svůj stávající systém vlády. V této své snaze apelovali na instinktivní podporu velké většiny britského politického národa a burcovali ji. “53

Takové postoje měly být základem konzervativního myšlení přinejmenším pro první třetinu 19. století, ne-li mnohem déle. Cílem konzervativců bylo zachovat co možná nejvíce z konstituce 18. století a tento cíl mimochodem sdíleli i mnozí whigové. To znamenalo řadu věcí: nenávist $\mathrm{k}$ demokracii a potlačování radikálů z nižších tříd; antipatii

51 Citováno tamtéž, s. 180-181.

52 Tamtéž.

53 Tamtéž. Dnes jsou britské postoje vůči Burkovi velmi př́ínivé, jak dokazuje nedávná studie toryovského poslance. Norman, Jess: Edmund Burke, Philosopher, Politician, Prophet. London 2013. Vyváženější postoj viz esej Ernesta Barkera „Burke on the French Revolution“ v jeho Essays on Government. Oxford 1945, s. 207-235. Skeptický názor viz výroční přednáška G. M. Younga v Britské akademii, přednesená 17. února 1943 a otištěná v Young, George M.: Today and Yesterday. Collected Essays and Addresses. London 1948, s. 83-109, v níž (str. 107) odsuzuje „slepý a infantilní konzervatismus, který Burke po téměř dvě generace vkládal do myšlení strany, jež vládla Anglii - zkrotila Napoleona.“ 
k protestantským nonkonformistům a k římským katolíkům, o židech a svobodných zednáŕích ani nemluvě; odpor proti jakýmkoli ústupkům vůči Irsku, v jehož př́padě se za nejlepší politiku pokládalo donucení - pohrdání Iry vlastně patřilo k patriotismu; a obranu vlastnictví. ${ }^{54}$ Burke prohlásil: „...první zásadou [vlády] musí být bezpečnost vlastnictví, protože právě kvưli ochraně vlastnictví byly všechny vlády ustaveny... to vlastnictví samo představovalo základ, na němž byla vláda utvořena. Kdyby se vytvoření vlády svěřilo nemajetným lidem, první, co by udělali, by samožrejmě bylo, že by okradli ty, kdo by majetek měli... účelem svobody bylo vlastnictví; a kdyby nemajetní dostali do rukou moc, brzy by začali loupit a vraždit. “55 Majetek však znamenal velký majetek, který zase znamenal aristokracii a jiné velké pozemkové vlastníky. Když vévoda z Wellingtonu v roce 1827 definoval stoupence strany toryů, řekl: „Naše strana sestává z biskupů a duchovních, vysoké aristokracie, vlastníků půdy, vysokých úředníků země, velkoobchodníků

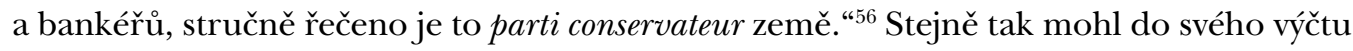
zahrnout i monarchii, ${ }^{57}$ která se od devadesátých let 18 . století stala předmětem přepjaté loajality. Jiří III. a Jiří IV. dávali přednost konzervativním ministrům a Wellington vě̌il, že všichni panovníci jsou konzervativní. Hlavními rádci Jiřího IV. skutečně byli právě Wellington a lord Sidmouth, oba z pravého kř́dla toryů, a i když v době rozvodového procesu pokládal král svého premiéra lorda Liverpoola za př́liš měkkého, nikdy tak docela nepřijal velmi nekompromisní toryovská stanoviska svého bratra, vévody z Cumberlandu. Liverpool tedy nahrazen nebyl. V důsledku těchto postojů spočívaly skutečné výdobytky toryů za dlouhé období jejich vlády v letech 1784-1830 nikoli, jak se vyjádřila jedna autorita, v několika chvályhodných učebnicových reformách, nýbrž - jak to chápali oni sami - v takových opatřeních, která např́íklad „až do roku 1869 chránila státní anglikánskou irskou církev a i poté ji zajistila většinu jejího majetku... nebo která omezila fiskální poplatky z majetkového dědictví na malou dědickou daň zaváděnou v osmdesátých a devadesátých letech 19. století. Když si tyto věci uvědomíme, snáze pochopíme, proč měla převážně konzervativní Sněmovna lordů v roce 1909 vetovat liberální rozpočet. " ${ }^{\text {"58 }}$

Toryismus měl samozřejmě svou lidovou podobu a obyvatelstvo se v letech Francouzské revoluce vášnivě stavělo proti radikálům. Whigové se dali přesvědčit k podpoře Pitta a jeho nástupců a radikály smetla vlna oficiálních represí. Nesmíme však zapomínat, že loajalismus byl populární záležitostí, na níž měli svůj podíl propagandisté jako John Bowles, William Jones, Hannah Mooreová a občas i William Cobbett. ${ }^{59}$ Tito pamfletisté volili přímější postup než Burke a propagandu zaměřovali na obyčejné lidi, před nimiž

54 Coleman, Bruce: Conservatism and the Conservative Party in Nineteenth Century Britain. London 1988, s. 4.

55 Tamtéž, s. 20.

56 Tamtéž, s. 21.

57 K tomuto tématu - mezi jinými jejími pracemi - viz Colley, Linda: The Apotheosis of George III: Loyalty, Royalty and the British Nation, 1760-1820. Past and Present 102, 1984; Táž: Britons. Forging the Nation, 1707-1837. New Haven 1992; Brooke, John: King George III. London 1972; Morris, Marilyn: The British Monarchy and the French Revolution. New Haven 1998.

58 Coleman, B.: Conservatism, s. 4.

59 Viz Dickinson, H. T.: Popular Conservatism and Militant Loyalism, 1789-1815. In: Britain and the French Revolution, Ed. T. H. Dickinson, s. 103-125. 
hájili privilegia krále a církve. Poukazovali na to, že obětmi revoluce, těmi, koho nejvíce postihují politické nepokoje, anarchie ve společnosti a vojenská agrese, jsou prostí, chudí Francouzi. Francouzi navíc svůj režim stavějí na abstraktních principech, kdežto Británie se těší konstituci založené na staletích praktických zkušeností a na zdravém rozumu. Zkrátka a dobře, zatímco francouzští revolucionáři ignorují pokyny Boha i omylnost člověka, Britům stále vládne přirozená aristokracie držící se náboženských zásad a sledující národní zájmy. Bůh, dávalo se chudým na srozuměnou, vytvořil přirozené nerovnosti, aby odměnil pilné a potrestal lenivé. Bohatí a chudí se navzájem potřebují: bohatí potřebují práci chudých a chudí dobročinnost bohatých. Rovnost by byla hrozbou dokonce i pro skrovný majetek poctivého pracujícího. Proti právům člověka, parlamentní reformě a všeobecnému volebnímu právu stavěli tito propagandisté praktickou možnost dovolat se spravedlnosti, vládu zákona a svobodu od státního útlaku. Chudí si zkrátka měli vážit konstituce, již Británii záviděl celý svět. A konečně, Francouzi byli proti křestanskému náboženství. Pod vedením militantních ateistů se zřekli tradičních ctností; britští chudí se měli chovat moudřeji: útěchu měli hledat v náboženství a měli zůstávat střízliví, skromní, pracovití a poslušní.

Britští reformátoři se svými záměry byli mezitím očerňováni a hanobeni jako hloupí důvěřivci, kteří naletěli cizí mocnosti, jako lidé, kteří chtěli svrhnout monarchii a nivelizovat společnost. Expanzionistické francouzské cíle v Evropě od panování Ludvíka XIV. sloužily k opodstatnění tvrzení, že chudí, vlastenečtí Britové nemají jinou volbu než bránit monarchii, církev a konstituci proti brutálním, ateistickým agresorům na druhé straně Kanálu. Konzervativní propaganda zdaleka převažovala nad propagandou radikální. V Londýně vycházely mimo jiné noviny a informační bulletiny Star, Sun, True Briton a Observer, v dalších oblastech země zase např́klad York Courant, Liverpool Phoenix, Manchester Mercury, Leicester Journal, Newcastle Courant, Caledonian Mercury a Edinburgh Herald. Ve městech, kde měli své noviny i radikálové, přetrvávaly jen konzervativní listy. A jiná konzervativní periodika si vedla ještě lépe, zejména Anti-Jacobin a British Critic. Je pravda, že události ve Francii - zářijové masakry, teror, poprava krále a královny, útoky na církev a její vlastnictví, napadení Nizozemí, Švýcarska a Itálie - vyděsily všechny vrstvy národa. Ale pomáhaly také verše, populární písně, karikatury a romány. Stejně tak pomáhaly i náboženské organizace, především evangelikální, například s velice úspěšnými Cheap Repository Tracts. Konference metodistů, Generální shromáždění skotské církve a vedoucí představitelé disenterů, ti všichni deklarovali svou loajalitu a král dostával stovky loajálních přípisů, kdykoli přežil nějaký pokus o úkladnou vraždu nebo se uzdravoval $\mathrm{z}$ nemoci.

Loajalisté rovněž zakládali ozbrojené milice a dobrovolné spolky k potlačení nepokojů a ochraně majetku. John Reeves tvrdil, že po celé zemi vzniklo neméně než 2000 takovýchto sdružení s názvy jako Asociace pro ochranu svobody a majetku proti republikánům a levellerům. Ve vesnických oblastech často stanuli v jejich čele pozemkoví vlastníci a smírčí soudci. Ale podporovali je nižší vrstvy. Tato sdružení nutila hostince, aby odmítaly pronajímat pokoje radikálům, sbírala o radikálech informace a přesvědčovala lidi, aby vstupovali do armády nebo námořnictva. Příležitostně propukaly i bouře proti radikálům a disenterům. Doklady, zdá se, svědčí o tom, že veškeré tyto aktivity byly spíše spontánní 
než podněcované vládou, ačkoli vláda skutečně udržovala rozsáhlou sít špehů a donašečů. Patrně je pravda, že „touha hájit britskou konstituci před jejími domácími kritiky a cizími nepřáteli se neomezovala na majetnou elitu, která mohla reformou a revolucí ztratit nejvíce. K obraně konstituce se šikovaly také střední a nižší vrstvy. “60

Období 1784-1830 tvoří, pokud jde o konzervatismus, jeden celek. A jeho jádro tvořila právě tato touha hájit konstituci, včetně monarchie a církve. To lze doložit dvěma způsoby. Za prvé, podíváme-li se na potlačování radikalismu, které trvalo až do poloviny třicátých let. A za druhé, podíváme-li se na to, jaké zájmy měli konzervativci v desetiletích po roce 1815 .

Pokud jde o první záležitost, v té době byla přijata celá řada zákonů namířených k potlačení opozice a podvratné činnosti, nemluvě o opakovaných legislativních opatřeních pozastavujících na určitá období platnost zákona Habeas Corpus. ${ }^{61}$ Přestože neexistuje žádný důkaz, že k nějaké podvratné činnosti skutečně docházelo, vláda nechtěla nic riskovat. Proto byl v roce 1795 přijat Zákon o vlastizradě, ve stejném roce Zákon o buřičských shromážděních a spolcích, dva zákony následující po námořních vzpourách v roce 1797 (které mimochodem neměly politickou příčinu), z nichž jeden zaváděl trest smrti pro osoby podněcující vzpouru a druhý stavěl mimo zákon př́ísežné sliby; v roce 1798 Tiskový zákon, v roce 1799 Zákon o spolčování, namířený proti odborovým svazům; ve stejném roce Zákon o nezákonných společnostech, který mimo jiné vedl k zákazu pěti předních britských radikálních společností; a v roce 1800 druhý Zákon o spolčování. Pak nastala v přívalu legislativy krátká přestávka do roku 1812, kdy byl přijat zákon trestající zločin rozbíjení strojů smrtí (v předešlém roce se vzbouřili luddité v textilních oblastech střední Anglie) a přitvrdil se trest za přísahu (nyní se stala hrdelním zločinem). Další přestávka pak trvala až do chvíle, kdy se země v důsledku ekonomické deprese, která se všude šíríila po konci napoleonských válek, přiblížila stavu vyhladovění. Shromáždění ve Spa Fields v Londýně v roce 1816 vedlo k menším nepokojům v londýnské City, které zase vláda využila $\mathrm{k}$ zavedení ještě represivnějších zákonů. V tomto roce byla opět pozastavena platnost zákona Habeas Corpus. Vláda zřejmě věřila, že existuje podzemní spiknutí, které chce svrhnout zákony a konstituci země. Tehdy byl nově vypracován Zákon o vlastizradě přijatý v roce 1817, který prodlužoval platnost Zákona o vlastizradě z roku 1795 a zpřrísňoval ho. Tato dvě opatření, nazývaná Sidmouthovy „Roubíkové zákony“ nebo „Dva zákony“, byla dosti drastická sama o sobě; v roce 1819 je pak následovalo Šest zákonů. Rok 1819 byl rokem velkého shromáždění na St. Peter’s Fields v Manchesteru, které skončilo tzv. masakrem „Peterloo“, když byli vysláni vojáci, aby zatkli hlavního řečníka, „orátora“ Hunta. Mezi reformátory nastalo všeobecné pobouření, ale represe s plnou podporou prince regenta pokračovaly. První ze Šesti zákonů zakazoval nepovolený výcvik nebo cvičení vojenského typu; druhý stavěl mimo zákon nošení zbraní a do-

60 Tamtéž, s. 124.

61 Následující výčet vychází z eseje G. D. H. Colea: „A Study in Legal Repression, 1789-1834“ v jeho Persons and Periods. Studies, původně vydaných v Londýně v roce 1938 a přetištěných v New Yorku v roce 1969, s. 120-142. Výzkum historiografie o buřičích a protestujících, kteří se stali obětí těchto represí viz Stevenson, John: Popular Radicalism and Popular Protest. In: Britain and the French Revolution, Ed. T. H. Dickinson, s. 61-81. 
voloval smírčím soudcům hledat a zabavovat zbraně; třetí umožňoval smírčím soudcům urychlovat soudní procesy s radikálními agitátory. Další tř̌i přiznávaly vládě výjimečné pravomoci k omezení svobody slova a shromaždování. Zákon proti buřičským shromážděním z roku 1819 nejen opětovně uzákonil opatření Zákona o vlastizradě z roku 1817, ale ještě více omezoval právo na shromažd’ování a ukládal přísnější tresty. Bezprostředně pak následoval Zákon proti buřičským pomluvám, který umožňoval zabavování buřičské nebo rouhačské literatury; a konečně, poslední z Šesti zákonů ukládal ještě těžší povinnosti novinám a jiným publikacím. Právě tento zákon donutil Williama Cobbetta, nejznámějš́ího novináře země, aby upustil od vydávání dvoupencové edice svého Political Register (známého jako „Dvoupencový brak“), který kdysi dosahoval nákladu 60000 výtisků týdně, a zvedl cenu této publikace na šest pencí. Stovky radikálních novinářů šlo raději do vězení, než by se podřídily tomuto zákonu, ale ten přetrvával. Vláda však měla v jednom ohledu štěstí. Cobbett byl tory, který toužil po štastné Anglii minulosti, to znamená po minulých dobách, kdy laskavá místní aristokracie údajně dobře zacházela s anglickými yeomany a farmáři. Jeho list pravidelně pranýřoval všechny politiky a vládní špehy, ale přestože často podporoval reformu, nikdy by neschvaloval revoluci. To bylo jen dobře, protože jak řekl jeden historik, vzhledem $\mathrm{k}$ jeho popularitě byl v letech po Waterloo Cobbett ,jediným Angličanem, který mohl vést revoluci“ ${ }^{62}$

Po roce 1819 dlouhý sled represivní legislativy dospěl ke konci. Poněkud neúčinné Zákony o spolčování byly v roce 1824 zrušeny, i když ještě roku 1834 se v Dorchesteru ze šesti zemědělských dělníků stali „mučedníci z Tolpuddle“, když byli obviněni z tajné př́sahy, že utvoří pobočku Velkého národního sjednoceného odborového svazu Roberta Owena. Anglie žasla, ale dokonce ani whigové a jejich stoupenci z řad pozemkových vlastníků na venkově nebyli ochotni připustit takový vývoj - ani ve „věku reformy“ po přijetí Reformního zákona v roce 1832.

Co lze říci o těchto opatřeních? Obhájci Pitta tvrdí, že nemohl mít žádnou představu, jak vážnou hrozbou jsou ve skutečnosti jakobíni, že tato opatření byla přechodná a kromě toho bylo veřejné mínění na jeho straně. Hlavní věcí bylo, že Británie prošla obdobím revoluce a napoleonských válek pod stabilní vládou. V roce 1820 bylo navíc odhaleno spiknutí v Cato Street, při němž bylo vybráno čtrnáct mužů, kteří měli zavraždit členy kabinetu při večeři v domě lorda Harrobyho; úřady však včas zakročily a spiklence uvěznily. Ministři si zřejmě už měsíce předtím uvědomovali, že jsou těmito rádoby atentátníky sledováni; jejich obavy snad proto nebyly tak nezdůvodněné.$^{63}$ Jiní zaujali současnější postoje k potlačování lidských práv těmito toryovskými vládami a odsuzovali Pittovu a následnou legislativu jako nemorální a zbytečnou. Ale jakkoli krutě vypadá taková legislativa se všemi tresty v podobě deportací, věznění a poprav z moderního hlediska,

62 Somervell, David C.: English Thought in the Nineteenth Century. London 1960, s. 38: „Říkalo se, že v letech po Waterloo mohla vypuknout nějaká anglická revoluce, ale faktem je, že jediným Angličanem, který mohl stanout v čele nějaké revoluce, hodil veškerou váhu svého vlivu na alternativní misku reformy. Cobbett např́klad pokáral luddity a vysvětloval jim situaci slovy, která by mohla uspokojit i ekonoma. Ze všech autorů z hnutí, které dotlačilo stranu whigů k přijetí Reformního zákona v roce 1832, byl Cobbett zdaleka nejvlivnějším."

63 Popis Metternicha z pera Castlereaghova bratra, britského vyslance ve Vídni viz Sked, Alan: Metternich and Austria. An Evaluation. Houndmills 2008, s. 106 [český překlad CDK 2014]. 
pro tehdejší konzervativce se pravděpodobně jednalo o minimum toho, co očekávali. ${ }^{64}$

Po roce 1815 se toryové stále drželi názoru, že oddanost konstituci znamená oddanost králi a církvi a pozemkovým elitám. K chudým zaujímali stále ten postoj, který vyložil John Weyland v roce $1807 \mathrm{v}$ pamfletu A Short Enquiry into the Poor Laws [Stručné zkoumáni chudinských zákonů]: chudinské dávky udržují bohatý rezervoár chudých lidí využitelných v základních průmyslových odvětvích. Bez těchto lidí by válka s Francií nemohla skončit vítězstvím. Weyland nevěřil, že v boji s pauperismem a neřestí by mohlo pomoci vzdělání. Chudí by se měli vzdělávat v Bibli a znát Knihu modliteb, ale znalost psaní nebo aritmetiky by jim $\mathrm{v}$ jejich hrubé práci nebyla $\mathrm{k}$ ničemu a ani by je neučinila spokojenějšími s jejich osudem. A navíc, není snad jasné, že kdyby chudí zbohatli, přestali by být pilní? A kdyby nebylo chudých, jak by si mohli bohatí zachovat své humánní a dobročinné pohnutky? Weyland podle názoru jednoho význačného historika „vyjádřil některá z nejzatvrzelejších přesvědčení “ řadových toryů ${ }^{65}$

Pokud jde o krále, většina toryů chtěla, aby jak panoval, tak i vládl. Jiří III. byl u nich v oblibě nikoli navzdory své politice vůči Americe nebo katolíkům, ale kvůli ní. A i když toryové nenáviděli koalice nebo spojenectví frakcí, věřili, že král má právo vybrat si „pestrou" vládu. Lord Eldon se chlubil, že ve funkci lorda kancléře držel velkou pečet jako králův služebník, nikoli jako ministr z nějaké strany. Politikové jako Eldon, a dokonce i Peel, vždy ospravedlňovali své jednání odkazem k tomu, že plní svou povinnost vůči králi. Wellington řekl, že nemohl odmítnout službu, pokud o ni požádal král, přestože to znamenalo sledovat politiku, která se mu protivila. A Peel v roce 1834 prohlásil: „Odporovalo by mému cítění, a vskutku mému smyslu pro povinnost, kdybych měl krále a monarchii vystavit ponížení tím, že bych odmítl úřad a vyzval služebníky, které propustil, aby se znovu ujali svých funkcí. Mé odmítnutí by se mohlo zakládat jen na otevřeném nesouhlasu s postupem krále." ${ }^{66}$ Důsledkem bylo zvěčňování dvorní teorie královských výsad, což mohlo představovat komplikaci, když se Jiří IV. tu a tam pokoušel svazovat ruce svých ministrů, pokud šlo o otázku katolíků, nebo zasahovat do zahraniční politiky. Problémy vyvolal i Vilém IV., když při jedné př́iležitosti tvrdil, že Lancasterské vévodství je jeho soukromým a nezávislým statkem, do něhož nemá parlament právo strkat nos. Prohlásil rovněž, že vysocí hodnostáři královského dvora jsou jeho osobní služebníky, které ministři nemohou z důvodu jejich odporu vưči vládní politice ve Sněmovně lordů odvolat. Jako nejvyšší velitel si rovněž nárokoval výlučný patronát nad armádou. Kromě toho trval na tom, že žádnému vyslanectví nelze bez jeho souhlasu posílat žádné instrukce, a v tomto požadavku ho v roce 1851 napodobila i královna Viktorie. ${ }^{67}$ Součástí toryovské doktríny snad bylo, že hranice královských výsad mají zůstat vágní, to ale nepochybně

64 Dobré pojednání o zásluhách Pitta a toryovské politiky obecně s ohledem na revoluční hrozbu viz O’Gorman, Frank: Pitt and the ,Tory' Reaction to the French Revolution, 1789-1815. In: Britain and the French Revolution, Ed. T. H. Dickinson, s. 21-37.

65 Davis, H. W. Carless: The Age of Grey and Peel. Being the Ford Lectures for 1926. Oxford 1929, s. 142. Mimořádně užitečná je sedmá kapitola Davisovy knihy, která nese název „Ideals of the Tory Party, 17841830 “. Většina ze zbývajících části tohoto článku vychází z jeho popisu.

66 Tamtéz, s. 148.

67 Tamtéz, s. 148-149. 
působilo problémy, at̉ už bylo pro torye jakkoli výhodné využívat loajalitu k monarchovi pro politické účely.

Toryové, státníci a literáti, se samozřejmě hluboce zajímali o církev. Eldon měl velký zájem o teologii a Liverpool byl oddaný evangelikál. Lord Sidmouth stál v čele hnutí za výstavbu nových kostelů ve velkých průmyslových centrech. V mnoha politických krizích hrála navíc důležitou roli Wilberforceova parlamentní skupina - Svatí. Wilberforce a lord Ashley byli jejími jedinými dvěma diskutéry, ale skupina měla ohromný vliv v otázkách morálky a náboženství; sám Wilberforce byl přítelem a mentorem Pitta a Percevala a ustavičně popichoval Addingtona, Liverpoola, Castlereagha a Canninga. Díky tomu byl schopen mobilizovat ve sněmovně většiny nezbytné ke zrušení obchodu s otroky. Jako křestan však podporoval státní církev, v níž viděl velký sjednocující prvek státu, zdroj zákona, řádu a civilizace. Souhlasil s Cokerem v tom, že „Westminsterské opatství je součástí konstituce“68 a že tělo konstituce by se nemohlo pohybovat bez své duše. Ale jak zajistit, aby byla církev stále efektivní? V tomto ohledu se vedly velké debaty o šíření vzdělání pod kontrolou církve a o zakládání nových farností v rostoucích průmyslových oblastech země. Do těchto debat se zapojili i Southey a Coleridge - kteří patřili k anglickým literárním kruhům, jež se po původním nadšení z Francouzské revoluce opět přiklonili na stranu řádu. ${ }^{69}$ Oba vycházeli z předpokladu, že jelikož rozum člověka je omylný a slabý, kdežto jeho vášně jsou silné, je nezbytné, aby mu vládl mravní zákon, který nemohl vymyslet sám, a inteligence, jež ho převyšuje. Southey se zaměřoval na sociální problémy. Odmítal jak politiku laissez-faire, tak zasahování státu do ekonomiky a chtěl, aby se sociální reforma uskutečnila prostřednictvím dobrovolného úsilí jednotlivců. Altruismus mělo podněcovat organizované křestanství. Jen náboženství mohlo poskytnout protilátku na jed otravující politický organismus. Anglikánskou církev pokládal za „nejlepší církevní zrrízení, jaké v současnosti existuje nebo jaké kdy existovalo“. ${ }^{70}$ Inspiroval ho středověk - doba, kdy náboženství vládlo společnosti a prostupovalo stát. Podle něj stát v současném světě postrádal účel, což vedlo k nadměrné osobní svobodě. Southey si ve skutečnosti přál nikoli návrat středověkých institucí, ale více středověké křestanské lásky a středověké úcty k autoritě; žáka našel v lordu Ashleym, pozdějším lordu Shaftesburym. Coleridge ve svých Principles of Political Knowledge [Principy politického poznání] z roku 1818 tvrdil, že jakákoli instituce může být ospravedlněna, jen pokud vede k dobrým výsledkům. Samotný rozum nepředstavoval žádné kritérium. Stát, prohlašoval, by měl nejen chránit život, svobodu a vlastnictví, ale měl by dělat vše pro zlepšení materiálních existenčních podmínek. Stát by tedy měl organizovat vhodnou dělbu práce, aby tyto podmínky zajistil, ačkoli by se na zlepšování svého života stále podíleli i jednotlivci. Ve své práci Constitution of Church and State [Konstituce církve a státu] z roku 1830 se zabýval morální odpovědností státu. Jelikož stát měl zásadní povinnost chránit náboženství, měla by existovat jakási národní inteligence či duchovní stav, vpravdě jakási národní

68 Tamtéž, s. 151. O Svatých viz s. 149-150.

69 Nejlepší pojednání o názorech literárních velikánů tohoto období viz Scott, Iain R.: , Things As They Are‘ The Literary Response to the French revolution, 1789-1815. In: Britain and the French Revolution, Ed. T. H. Dickinson, s. 229-249. 
církev, která by měla povinnosti přesahující pouhý výklad teologie. Tato inteligence by se dělila na dvě tř́dy - jedna by vzdělávala laiky a druhá by, na vyšší úrovni, vzdělávala zase ji. Vzdělávání mládeže by se však obecně mělo svěrit církvi, která měla poskytovat také občanskou výchovu a vštěpovat jí občanská práva a povinnosti. Tímto způsobem by se dal vytvořit národ „poslušných, svobodných, užitečných a organizovatelných poddaných, občanů a vlastenců, kteří by svůj život zasvětili blahu státu“ “. ${ }^{71}$ Nepochybně byl i on ovlivněn středověkou teologií a praxí.

V oné době však neexistovala v náboženských otázkách velká shoda. Otázka církve v Irsku, emancipace katolíků, patronát státu v rámci anglikánské církve, rostoucí rozkoly ve skotské církvi nebo role státní církve a ostatních církví ve vzdělávání představovaly nekonečné problémy. Standardní postoj konzervativců však zůstával protikatolický, protiirský a příznivě nakloněný zachování statu quo 18. století. Příliš tedy neudivuje, že se strana rozdělila v otázce emancipace katolíkủ v roce 1829 a zrušení obilních zákonů v roce 1846. Proč tedy Wellington a Peel souhlasili s uzákoněním těchto opatření? Proto, že by je tak jako tak prosadili whigové, lord Grey v roce 1829 a lord Russell v roce 1846 ? Avšak Peel je nepokládal za přijatelné. $V$ každém případě byl přesvědčen o tom, že jen on může získat královský souhlas a uzákonit je, že je v obou př́padech nepostradatelný. Jak řekl jeden moudrý historik: „Praktickým cílem, který sledoval, at̉ už byl u moci, nebo v opozici, bylo udržet pohromadě stranu, z níž pocházel a s jejíž pomocí vyrostl. Raison d'être této strany byl podle něho udržet tak velkou část konstituce z 18. století, jaká se ještě dala ubránit. Torye pokládal za obleženou posádku, jejímž právem a povinností bylo evakuovat a strhnout neudržitelné pozice, aby to, co z pevnosti zůstalo, mohla udržet déle. Vždycky vycházel z předpokladu, že majíli už změny nastat, bezpečněji je provedou toryové, nejlépe pod jeho vlastním vedením, než jakýmkoli jiným způsobem."72

Jeho tragédií bylo, že toryové stále reprezentovali ancien régime, který neměl žádnou chut "evakuovat a strhnout neudržitelné pozice“ nebo přistupovat na kompromisy, jež pokládali za zbytečné a škodlivé pro národní zájmy, to znamená pro zájmy protestantů a pozemkových vlastníků. Po většinu 19. století zůstávali britští konzervativci ve vleku Burka a 18. století.

71 Tamtéž, s. 158.

72 Tamtéž, s. 299. 


\section{British Conservatism in the Early 19th Century}

This study examines the issue of British conservatism in the early 19th century. The author works with a definition of conservatism as proposed by the German historian Hans-Gerd Schumann and occasionally also utilizes the typology of Klaus Epstein which distinguishes three types of conservative: status quo conservatives, reform conservatives and reactionaries. First of all, he evaluates the role of the founding figure of British conservatism Edmund Burke, his thinking and influence on the tradition of conservative political thought and in realpolitik in Britain from the end of the 18th century and in the first half of the following century. This topic is set within the context of British foreign policy in relation to revolutionary France and then also in relation to the distribution of power on the continent after 1815. The author demonstrates that British politics was primarily governed by the principle of territorial conservatism, i.e. an attempt to maintain the territorial arrangements from 1815 and to ensure national security in the face of a potential threat from France. Similarly, the author also analyzes the parameters of British conservative domestic policy, describing how conservatives were largely succesfully in convincing broad swathes of the population that radicalism of the French type would quickly make its negative effects felt across the whole of society. However, he sees the main problem of the conservatives and their policies as being the fact that for most of the 19th century they remained in thrall to Burke and the 18th century.

Článek přeložil Jiřri Ogrocký. 
